\section{OPEN ACCESS}

Edited by:

Paolina Garbeva,

Netherlands Institute of Ecology (NIOO-KNAW), Netherlands

Reviewed by:

Steffen Kolb,

Leibniz Centre for Agricultural

Landscape Research (ZALF),

Germany

Petri Penttinen,

Zhejiang Agriculture and Forestry

University, China

*Correspondence:

Daniel C. Schlatter

daniel.schlatter@ars.usda.gov

Specialty section:

This article was submitted to

Terrestrial Microbiology,

a section of the journal

Frontiers in Microbiology

Received: 02 February 2019

Accepted: 29 May 2019

Published: 26 June 2019

Citation:

Schlatter DC, Reardon CL, Johnson-Maynard J, Brooks E, Kahl K, Norby J, Huggins D and

Paulitz TC (2019) Mining

the Drilosphere: Bacterial

Communities and Denitrifier Abundance in a No-Till Wheat

Cropping System

Front. Microbiol. 10:1339. doi: 10.3389/fmicb.2019.01339

\title{
Mining the Drilosphere: Bacterial Communities and Denitrifier Abundance in a No-Till Wheat Cropping System
}

Daniel C. Schlatter ${ }^{1 *}$, Catherine L. Reardon'2, Jodi Johnson-Maynard ${ }^{3}$, Erin Brooks ${ }^{3}$,
Kendall Kahl ${ }^{3}$, Jessica Norby ${ }^{3}$, David Huggins ${ }^{4}$ and Timothy C. Paulitz

${ }^{1}$ Wheat Health, Genetics and Quality Research Unit, Agricultural Research Service, United States Department of Agriculture, Pullman, WA, United States, ${ }^{2}$ Soil and Water Conservation Research Unit, Agricultural Research Service, United States Department of Agriculture, Adams, OR, United States, ${ }^{3}$ Department of Soil and Water Systems, University of Idaho, Moscow, ID, United States, ${ }^{4}$ Northwest Sustainable Agroecosystems Research Unit, Agricultural Research Service, United States Department of Agriculture, Pullman, WA, United States

Earthworms play important roles in no-till cropping systems by redistributing crop residue to lower soil horizons, providing macropores for root growth, increasing water infiltration, enhancing soil quality and organic matter, and stimulating nitrogen cycling. The soil impacted by earthworm activity, including burrows, casts, and middens, is termed the drilosphere. The objective of this study was to determine the effect of earthworms on soil microbial community composition in the drilosphere at different landscape slope positions. Soil cores $(50 \mathrm{~cm}$ depth) were extracted from three landscape locations (top, middle, and bottom slope positions) on a sloping aspect of a no-till wheat farm. Soil was sampled at the bottom of the soil core from inside multiple earthworm (Lumbricus terrestris) channels (drilosphere) and from adjacent bulk soil. Bacterial communities were characterized for 16S rRNA gene diversity using high-throughput sequencing and functional denitrifier gene abundance (nirK, nirS, and nosZ) by quantitative PCR. Bacterial communities were structured primarily by the landscape slope position of the soil core followed by source (bulk versus drilosphere soil), with a significant interaction between core position and source. The families AKIW874, Chitinophagaceae, and Comamonadaceae and the genera Amycolatopsis, Caulobacter, Nocardioides, and Variovorax were more abundant in the drilosphere compared to the bulk soil. Most of the individual bacterial taxa enriched in the drilosphere versus bulk soil were members of Actinobacteria, including Micrococcales, Gaiellaceae, Solirubrobacterales, and Mycobacterium. In general, the greatest differences in communities were observed in comparisons of the top and bottom slope positions in which the bottom slope communities had significantly greater richness, diversity, and denitrifier abundance than the top slope position. Populations of denitrifiers (i.e., ratio of nirK+nirS to $16 \mathrm{~S}$ rRNA) were more abundant in earthworm-impacted soils and there was a significant impact of $L$. terrestris on soil community composition which was observed only in the top landscape position. 
There were significant correlations between the abundance of nirK and nirS and taxa within Proteobacteria, Acidobacteria, Actinobacteria, Verrucomicrobia, and Chloroflexi, suggesting a broad diversity of denitrifying bacteria. Earthworms influence the soil microbial communities, but the impact depends on the slope location in a variable landscape, which likely reflects different soil characteristics.

Keywords: earthworms, soil, microbiome, next-generation sequencing, direct seed, Pacific Northwest

\section{INTRODUCTION}

As ecosystem engineers, earthworms play a major role in the formation of soil and have profound effects on the physical, chemical, and biological properties of the below-ground environment (Lavelle et al., 2016). Earthworms are important in agricultural systems for litter decomposition (Cortez, 1998), microaggregate formation (Pulleman et al., 2005), penetration of roots through compacted soil (Edwards and Lofty, 1980), and water infiltration (Willoughby et al., 1997). Additionally, positive effects of earthworms on crop productivity have been observed for both crop yield and aboveground biomass, with the plant benefit attributed to the release of nitrogen from organic matter and crop residues (van Groenigen et al., 2014). The volume of soil impacted by earthworms, termed drilosphere, includes casts, middens, burrows, and burrow linings, and influences from physical features of earthworms (body surface, gut, and internal features) and secretions (e.g., mucus, sloughed off cells) (Brown et al., 2000).

As a result, the drilosphere is enriched in labile carbon promoting microbial "hotspots" with increased microbial and macrofaunal biomass (Tiunov et al., 2001; Don et al., 2008; Stromberger et al., 2012), as well as soil enzyme activity for organic matter breakdown compared to the bulk soil (Görres et al., 2001; Don et al., 2008; Beloqui et al., 2010; Hoang et al., 2016a,b). Using labeled carbon (C) and nitrogen (N), Andriuzzi et al. (2013) calculated the dimensions of the zone of influence to be greater than $2 \mathrm{~mm}$, possibly $4-8 \mathrm{~mm}$ in soil surrounding earthworm burrows.

In minimum disturbance systems, deep-burrowing anecic earthworms are important in burying surface residue in the soil profile for decomposition. Lumbricus terrestris, colloquially known as a nightcrawler, is an introduced species that is now commonly found in natural and agricultural soils throughout North America. These anecic earthworms create deep vertical burrows in soil that can increase water infiltration and $\mathrm{O}_{2}$ levels in soils (Willoughby et al., 1997), and provide preferential pathways for growing plant roots (Edwards and Lofty, 1980; Cameron et al., 2014). The burrows can remain in soil as stable structures lasting up to 7 years, where they are spatiotemporally stable reservoirs of soil resources (Potvin and Lilleskov, 2017). Earthworms translocate organic matter into these burrows by the physical movement of large amounts of plant residue (Curry and Schmidt, 2007) and by the deposition of mucus and casts. Earthworm activity results in significant changes in soil properties, such as greater amounts of microbial biomass $\mathrm{C}$ and $\mathrm{N}$, mineralizable $\mathrm{C}$, and nitrate compared to undisturbed soil (Burtelow et al., 1998). In addition, earthworm-impacted soils also exhibit greater denitrification activity than bulk soils (Burtelow et al., 1998).

The earthworm gut is anoxic, high in organic $\mathrm{C}$ and inorganic $\mathrm{N}$, and host to abundant populations of denitrifying bacteria (Horn et al., 2003). Denitrifying population densities in the earthworm gut can far exceed that of the bulk soil. For example, the abundance of cultivable denitrifiers in the Lumbricus rubellus gut are 256-times greater than in bulk soil (Karsten and Drake, 1997). The earthworm gut emits $\mathrm{N}_{2} \mathrm{O}$ and $\mathrm{N}_{2}$, both of which are attributed to the gut microbial communities (Ihssen et al., 2003; Horn et al., 2006; Nebert et al., 2011; Chen and Whalen, 2016).

It is hypothesized that the denitrifying populations are derived from soil rather than being gut-specific, and that the microenvironment of the gut promotes $\mathrm{N}_{2} \mathrm{O}$-production (Horn et al., 2003). Similarly, earthworm guts and casts have greater capacities for denitrification than the surrounding soil (Svensson et al., 1986; Matthies et al., 1999). However, little is known regarding the microbial community composition and structure of the earthworm drilosphere, which is also enriched in microbial biomass and activity (respiration) compared to non-impacted or nearby bulk soil (Tiunov and Scheu, 1999; Tiunov and Kuznetsova, 2000).

With some exceptions, microbial communities in the drilosphere are poorly characterized. Studies in the late 1990s with culturable bacteria showed high levels of Pseudomonas and siderophore-producing bacteria (Devliegher and Verstraete, 1997) and Bacillus (Biswas et al., 2014). Byzov et al. (2009) cultured bacteria and fungi from soil and casts and identified them by sequencing the bacterial $16 \mathrm{~S}$ rRNA and fungal $28 \mathrm{~S}$ rRNA (D1/D2 domain) gene sequences. They identified the families Aeromonadaceae, Comamonadaceae, Enterobacteriaceae, Flavobacteriaceae, Moraxellaceae, Pseudomonadaceae, and Sphingobacteriaceae. Using phospholipid fatty acid analysis (PLFA), Stromberger et al. (2012) found distinct microbial and faunal communities in the L. terrestris drilospheres, with greater abundance of microbes, microfauna including protozoa, nematodes, and mesofauna (e.g., Collembola), in the drilosphere compared to nearby bulk soil. Similarly, Banfield et al. (2017) used PLFA to show higher levels of microbes in both the drilosphere and biopores. Using Single-Strand Confirmation Polymorphisms (SSCP) and sequence analysis of $16 S$ rRNA clone libraries, Nechitaylo et al. (2010) showed that L. terrestris contained representatives of classes Flavobacteria and Sphingobacteria (Bacteroidetes) and Pseudomonas spp. using Automated Ribosomal Intergenic Spacer Analysis (ARISA), Thakuria et al. (2010) demonstrated that the bacteria in guts of different ecological groups (anecic L. terrestris and L. friendi, the endogeic Aporrectodea caliginosa and A. longa) 
were distinct, and that habitat was a greater determinant than earthworm species.

In this study, we evaluated effects of earthworms on the soil microbial communities focusing on differences between bulk and drilosphere soil. The study was conducted to evaluate whether bacterial communities of drilosphere soil differed from those of bulk soil.

In the Palouse region of eastern Washington state, high wheat yields (average yield 4.43 tons $\mathrm{ha}^{-1}$ in Whitman county; NASS Quick Stats) leave a tremendous amount of wheat residue on the soil surface in direct-seed systems (around $3500 \mathrm{~kg} \mathrm{C} \mathrm{ha}^{-1} \mathrm{yr}^{-1}$ ) (Huggins et al., 2014). The combination of high residue inputs and reduced or no tillage promotes greater earthworm densities due to the provision of a large food base and reduced disturbance (Peigné et al., 2009; Rothwell et al., 2011). Few studies, however, have used high-throughput DNA sequencing (HTS) to examine microbial communities associated with $L$. terrestris in the drilosphere. The objective of this research was to use HTS to characterize the bacterial communities of the drilosphere of $L$. terrestris under a direct-seed system, and compare them to the adjacent bulk soil. We hypothesized that the drilosphere contains a more rich and diverse community than bulk soil and is enriched in denitrifying populations and taxa capable of breaking down crop residues.

\section{MATERIALS AND METHODS}

\section{Site Description}

The study was conducted in the dryland, temperate Palouse region of the inland Pacific Northwest which is noted for its topographically sloping agricultural landscape. Samples were collected from three slope positions (top-slope, mid-slope, and bottom-slope) at the R.J. Cook Agronomy Farm (CAF), a USDA Long-Term Agroecosystem Research (LTAR) site in WA, United States $\left(46^{\circ} 46^{\prime} 44^{\prime \prime} \mathrm{N}, 117^{\circ} 05^{\prime} 19^{\prime \prime} \mathrm{W}\right)$. The CAF has been managed in a 3-year winter wheat-spring grain-pulse crop rotation following no-tillage practices since 1998. Historically water and tillage-induced erosion across the region have dramatically altered the distribution of soils within these landscapes (USDA, 1978). Upper eroded locations (top-slopes) often have less topsoil and produce lower yields than deposition regions (Fiez et al., 1995). However, the soil was classified by USDA-ARS soil scientists a Palouse silt loam (Fine-silty, mixed, superactive, mesic, Pachi, Ultic, Haploxerolls) having a well-drained mollic epipedon from the surface to $61 \mathrm{~cm}$ over a thick cambic horizon from 61 to $150 \mathrm{~cm}$. The bottom-slope position was a Thatuna silt loam, fine-silty, mixed, superactive, mesic Oxyaquic Argizerolls which has a mollic epipedon zone from the surface to a depth of $69 \mathrm{~cm}$, followed by an albic horizon from 69 to $94 \mathrm{~cm}$, and a dense argillic horizon from 94 to $163 \mathrm{~cm}$. The mid-slope was a Palouse silt loam soil. In comparison to field averages, ridge locations characteristic of the top-slope core position produce $20 \%$ less crop yield; whereas, the north facing slope of the bottom- and mid-slope core positions normally yield $20 \%$ greater than the field average (Huggins et al., 2014). Soil horizon descriptions for each of the landscape positions are provided in Supplementary Table 1.

\section{Soil Sampling}

Large, undisturbed soil cores were collected October 6, 2016 from the top-slope (811.6 m elevation), mid-slope $(801.6 \mathrm{~m})$, and bottom-slope $(791.6 \mathrm{~m})$ at CAF (Figure 1A). Steel cylinders $(25-\mathrm{cm}$ inside diameter by $50 \mathrm{~cm}$ long) were driven vertically into the soil using an electric powered post driving machine. The soil surrounding the core was removed manually by digging, and the cylinder retaining the soil core carefully lifted

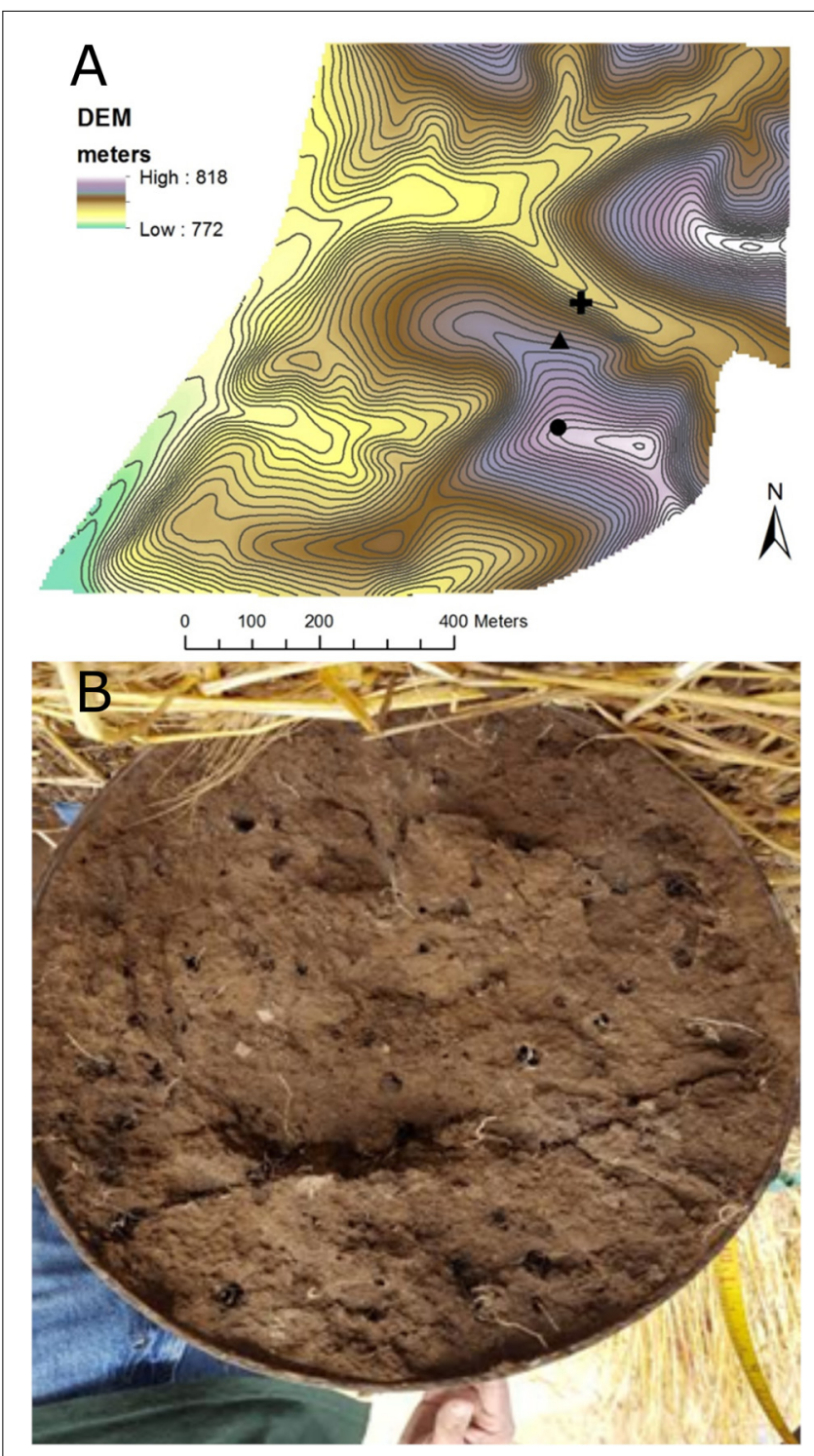

FIGURE 1 | (A) Map showing the locations of the top-slope (circle), mid-slope (triangle), and bottom-slope (plus sign) core positions within the Cook Agronomy Farm. Contour intervals are $1 \mathrm{~m}$. (B) Example of earthworm burrows found in the $25 \mathrm{~cm}$ (10 inch) diameter extracted soil cores (viewed from the bottom at a depth of $50 \mathrm{~cm}$ ). 
and transported to the lab. Many earthworm burrows were visible at the bottom (50-cm depth) of each core (Figure 1). Earthworm burrows ( $n=6$ per core) were sampled from the core bottoms by scraping the inside of an individual channel with a sterilized powder scoop. We could not distinguish active from abandoned earthworm burrows; however, sampled burrows were large, continuous and lacked clear signs of root growth of substantial enough size to limit earthworm use of the burrows. Bulk soil was sampled $(n=4)$ from arbitrary points on core bottoms at a distance of at least $5 \mathrm{~mm}$ away from the earthworm channels (Figure 1B). Bulk density was measured at the collection site from replicate cores $(5 \mathrm{~cm}$ diameter $\times 5 \mathrm{~cm}$ length) extracted from the side walls of the hole at three depths $(0-5 \mathrm{~cm}, 20-25 \mathrm{~cm}, 35-40 \mathrm{~cm})$ (Supplementary Table 2). While earthworms were not directly sampled, middens were present throughout the CAF field, with an average value of $11 \pm 6$ middens $\mathrm{m}^{-2}$ measured on the same slope positions and aspects within $175 \mathrm{~m}$ of where the drilosphere cores were taken (data not shown). In a recent survey of agricultural fields in the inland Pacific Northwest, which included the CAF, $L$. terrestris was the only anecic, midden-producing species sampled from fields located in the annual cropping region (Walsh and Johnson-Maynard, 2016).

\section{DNA Extraction and Amplicon Sequencing}

DNA was extracted from $0.25 \mathrm{~g}$ soil using the PowerSoil DNA extraction kit (Qiagen/MoBio, Carlsbad, CA, United States) according to the manufacturer's instructions with bead-beating performed on a FastPrep system using the "soil" setting. The amount of DNA extracted from the burrows was similar across the landscape position (average concentration of $5.7 \mathrm{ng} \mu \mathrm{l}^{-1}$ ) and the amount of DNA extracted in bulk soil varied across slope position with $1.4 \mathrm{ng} \mu \mathrm{l}^{-1}$ from the top slope, $11.3 \mathrm{ng} \mu \mathrm{l}^{-1}$ from midslope and $16.9 \mathrm{ng} \mu \mathrm{l}^{-1}$ from the bottom slope. DNA was normalized, amplified using 27F (Edwards et al., 1989) and 518R (Øvreås et al., 1997) primers targeting the V1-V3 region of the 16S rRNA gene, barcoded, and sequenced on the Illumina MiSeq platform (Version 3 chemistry, $2 \times 300$ paired-end reads) according to established protocols (Gohl et al., 2016).

\section{Quantitative PCR}

Bacteria and denitrifying populations were quantified by qPCR based on the abundance of genes encoding the bacterial 16S rRNA, copper nitrite reductase (nirK), $c d_{1}$ nitrite reductase (nirS), and nitrous oxide reductase (nosZ) (Supplementary Table 3). DNA extracts were diluted 1:20 and tested for the presence of PCR inhibitors according to published protocols prior to quantification (Reardon et al., 2014). None of the extracts showed signs of PCR inhibition and the $\mathrm{C}_{\mathrm{q}}$ (quantification cycle) of reactions with soil DNA varied less than $0.3 \mathrm{C}_{\mathrm{q}}$ from the soil DNA-free control. Quantification was performed in $10 \mu \mathrm{l}$ reactions with $0.8 \times$ Power SYBR Green Master Mix (Life Technologies, Grand Island, NY), $0.1 \mu g \mu l^{-1}$ bovine serum albumin (Roche Applied Science, Indianapolis, IN, United States), forward and reverse primer (Supplementary Table 3), and $1 \mu$ DNA diluted 1:20. Standard curves were generated by 10 -fold dilution of plasmid containing the gene targets for a range of 5-6 orders of magnitude. Thermocycling conditions are presented in the Supplementary Table 4. Fluorescence was measured at the end of each complete cycle and the amplification was followed by a final melt curve. All protocols were specifically optimized for the SYBR reagent and instrument.

\section{Data Processing}

Read preparation and operational taxonomic unit (OTU) clustering were performed according to the UPARSE pipeline (Edgar, 2013) as described in the Supplementary Table 4.

Taxonomy was assigned to OTU representative sequences (centroids) with the RDP Naïve Bayesian Classifier (Wang et al., 2007) using the Greengenes 13_8 reference database and an $80 \%$ confidence threshold. OTUs were filtered to remove any OTUs that could not be classified to the kingdom Bacteria or those classified as mitochondria or chloroplasts using QIIME scripts (v1.9.1) (Caporaso et al., 2010). OTUs with a total sequence count of $<10$ were removed to reduce poor quality OTUs and the OTU table was rarefied to 13,000 sequences/sample prior to analysis. Unrarefied OTU tables were retained for differential abundance analysis with DESeq2 (v1.12.4) (Love et al., 2014).

\section{Data Analysis}

Non-metric multidimensional scaling (NMDS) and PERMANOVA were performed using Bray-Curtis dissimilarity among samples to assess the significance of the landscape position of the core and sample source (bulk soil versus earthworm drilosphere) on bacterial community structure using the metaMDS and adonis functions of the vegan package v2.4.1 (Oksanen et al., 2016) in R (R Core Team, 2016). OTU richness and diversity metrics (Shannon's [H'] and inverse Simpson's $[1 / D])$ were estimated from rarefied OTU tables and tested using ANOVA. Bacterial families and genera that differed in relative abundance between bulk soil and earthworm channels were evaluated with Kruskal-Wallis tests on abundant groups ( $>0.5 \%$ of sequences), followed by correction for false discovery using the Benjamini-Hochberg procedure. DESeq2 was used to identify differentially abundant OTUs (DAotus) between bulk or drilosphere soil. Briefly, unrarefied OTU tables were filtered to contain only OTUs with normalized counts $>20$ and present in three or more samples. DAotus were evaluated after accounting for core identity using the model: $\sim$ Core Position $\times$ Soil Source. Contrasts were performed between bulk and channel soil for each core and OTUs with adjusted $p$-values of $<0.001$ and $\log 2$-fold changes $>2$ were considered to be differentially abundant. Relationships between abundant OTUs ( $>100$ sequences in rarefied data) and copy numbers of nirK and nirS genes were evaluated using Spearman correlations. Finally, the abundance of nirK and nirS genes and their ratios with 16S rRNA gene abundance were compared among landscape positions and between bulk and drilosphere soil with ANOVA and nested ANOVA, respectively. 


\section{RESULTS}

Sequence processing resulted in a total of 749,959 sequences belonging to 5,509 bacterial OTUs among 30 samples $(364,000$ sequences belonging to 4,322 OTUs after rarefaction). Bacterial communities from both bulk soil and earthworm channels were dominated by Actinobacteria (29-42\% and $30-45 \%$, respectively), Proteobacteria (14-17\% and 16-18\%, respectively), and Acidobacteria (13-15\% and $11-14 \%$, respectively), with other common phyla including Chloroflexi, Firmicutes, Nitrospirae, Gemmatimonadetes, and Verrucomicrobia (Figure 2). Overall, bacterial communities were affected primarily by the landscape slope position of the soil core (Figure 3; adonis $r^{2}=0.498, p=0.001$ ), followed by source (bulk versus drilosphere soil; Figure 3; adonis $r^{2}=0.075$, $p=0.001)$ with a significant interaction between core slope position and source (Core Position $\times$ Source adonis $\left.r^{2}=0.058, p=0.04\right)$. However, within individual soil cores, soil source explained a significant amount of variation in bacterial community structure only in the top-slope core (adonis $r^{2}=0.39, p=0.002$; Figure 3 ). Thus, within-field variation in microbial community composition was a larger factor in determining overall bacterial community structure than earthworm-soil interactions. However, the significance of the drilosphere effect for bacterial communities in earthworm macropores depended on landscape slope position (Figure 3).

The relative abundances of many bacterial families differed significantly among soils from different field landscape slope positions (Figure 4). Specifically, families

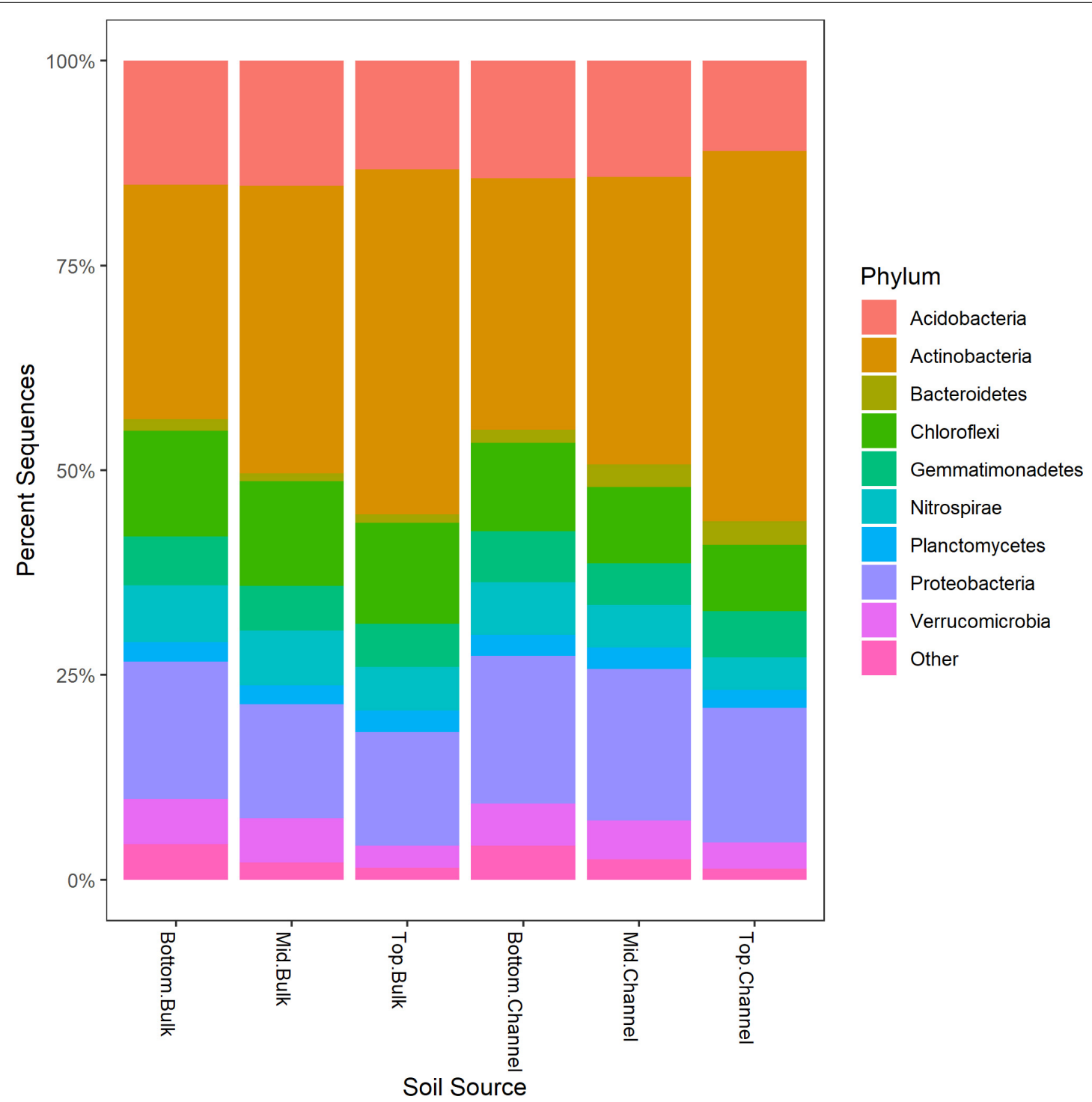

FIGURE 2 | Relative abundance [ $\log _{2}(1+x)$-transformed rarefied sequence counts] of bacterial phyla among slope positions (top-, mid-, bottom-slope) and soil sources (bulk, channel). Top, mid, and bottom refer to slope positions. 

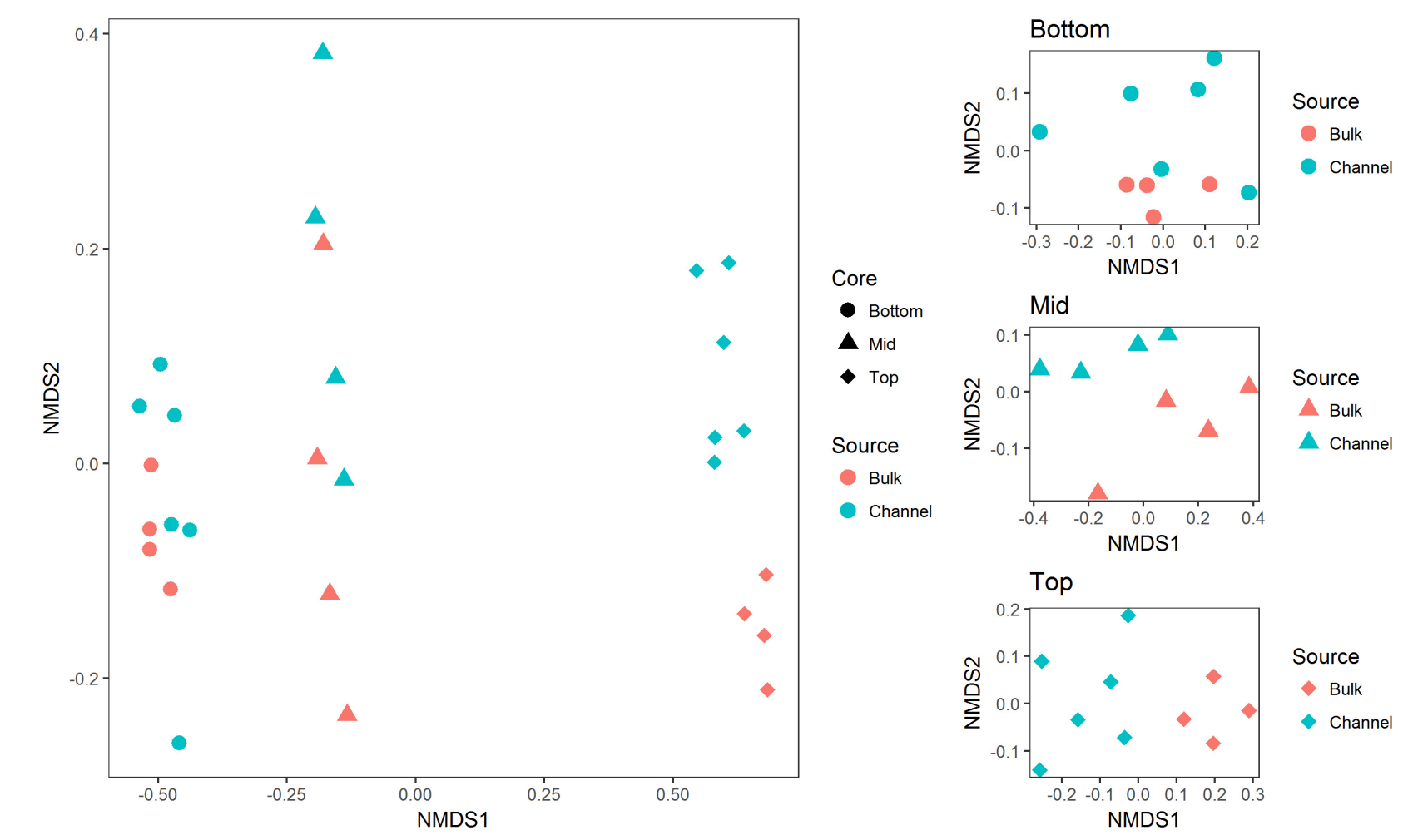

FIGURE 3 | Non-metric multidimensional scaling plots of bacterial communities among (left; Stress = 0.044), and within individual soil cores (right; Stress = 0.09, 0.02, and 0.06 for bottom-, mid-, and top-slope samples, respectively). Top, mid, and bottom refer to slope positions.

more prevalent in soils from the top-slope versus mid- or bottom-slope soils included Nocardioidaceae, Rhodospirillaceae, Mycobacteriaceae, Phyllobacteriaceae, Streptomycetaceae, and Solirubrobacteriaceae. In contrast, those families more abundant in mid- or bottom-slope soils than top-slope soils included Koribacteriaceae (Acidobacteria) PRR-10, Methylophilaceae, and Propionibacteriaceae (Figure 4). Similarly, at the genus level, Streptomyces, Kribbella, Mycobacterium, Chitinophaga, Pseudonocardia, Phyllobacterium, Mesorhizobium, and Steroidobacter were relatively more abundant in top-slope soils than mid- or bottom-slope soils. Members of DA101 (Verrucomicrobium) and Candidatus Solibacter were of greater relative abundance in mid-and bottom-slope soils than top-slope soils (Figure 5).

Despite the major role of landscape slope position in determining bacterial community structure, a small number of bacterial taxonomic groups were enriched in earthworm burrows.

Namely, the families Pseudonocardiaceae, Nocardiaceae, Propionibacteriaceae, Caulobacteraceae, Rhodospirillaceae, Thermomonosporaceae, Chitinophagaceae, and Comamonadaceae had higher relative abundance in earthworm channels than in bulk soil (KW-test, FDR-corrected $p$-values $<0.1$ ). Moreover, at the genus-level of classification, Amycolatopsis (KW-test, FDR $p=0.024$ ), Caulobacter (KW-test, FDR $p=0.028$ ), Nocardioides (KW-test, FDR $p=0.042)$, Chitinophaga (KW-test, FDR $p=0.028)$, and Variovorax (KW-test, FDR $p=0.025$ ) were more prevalent in earthworm drilosphere versus bulk soil. Finally, at the OTU-level, some OTUs were significantly associated with bulk or drilosphere soil (Figure 6). Most of these OTUs belonged to the phylum Actinobacteria and Proteobacteria, including taxa related to Micrococcus and Gaiellaceae.

Bacterial richness and diversity varied significantly with slope position and between earthworm channels and bulk soil. In general, bacterial richness and diversity corresponded with the slope position, where soil from the bottom slope tended to have the highest richness and diversity and soil from the top slope tended to have the lowest (Table 1; ANOVA $F=22.8$, 35.9, and 30.41 for richness, Shannon $\mathrm{H}^{\prime}$, and Simpsons 1/D, respectively; $p<0.001$ in each case). Both Shannon $\mathrm{H}^{\prime}$ and Simpsons 1/D indices of diversity were significantly greater in earthworm drilospheres than in bulk soil, though individual contrasts were often not statistically significant between bulk versus drilosphere soil within cores (Table 1, ANOVA $F=13.55$ and 19.13, $p=0.001$ and 0.0002 for Shannon $\mathrm{H}^{\prime}$ and Simpsons $1 / \mathrm{D}$, respectively).

The abundance of genes related to denitrification (nirK and nirS) varied significantly by landscape slope position $(p=0.043$ and $p=0.021$, respectively; Figure 7 and Supplementary Table 4). However, the numbers of bacterial 16S rRNA genes, which ranged from $9.6 \times 10^{4}$ to $1.49 \times 10^{5}$ copies $\mathrm{ng}^{-1} \mathrm{DNA}$, were similar across all positions $(p=0.097)$. The abundance 


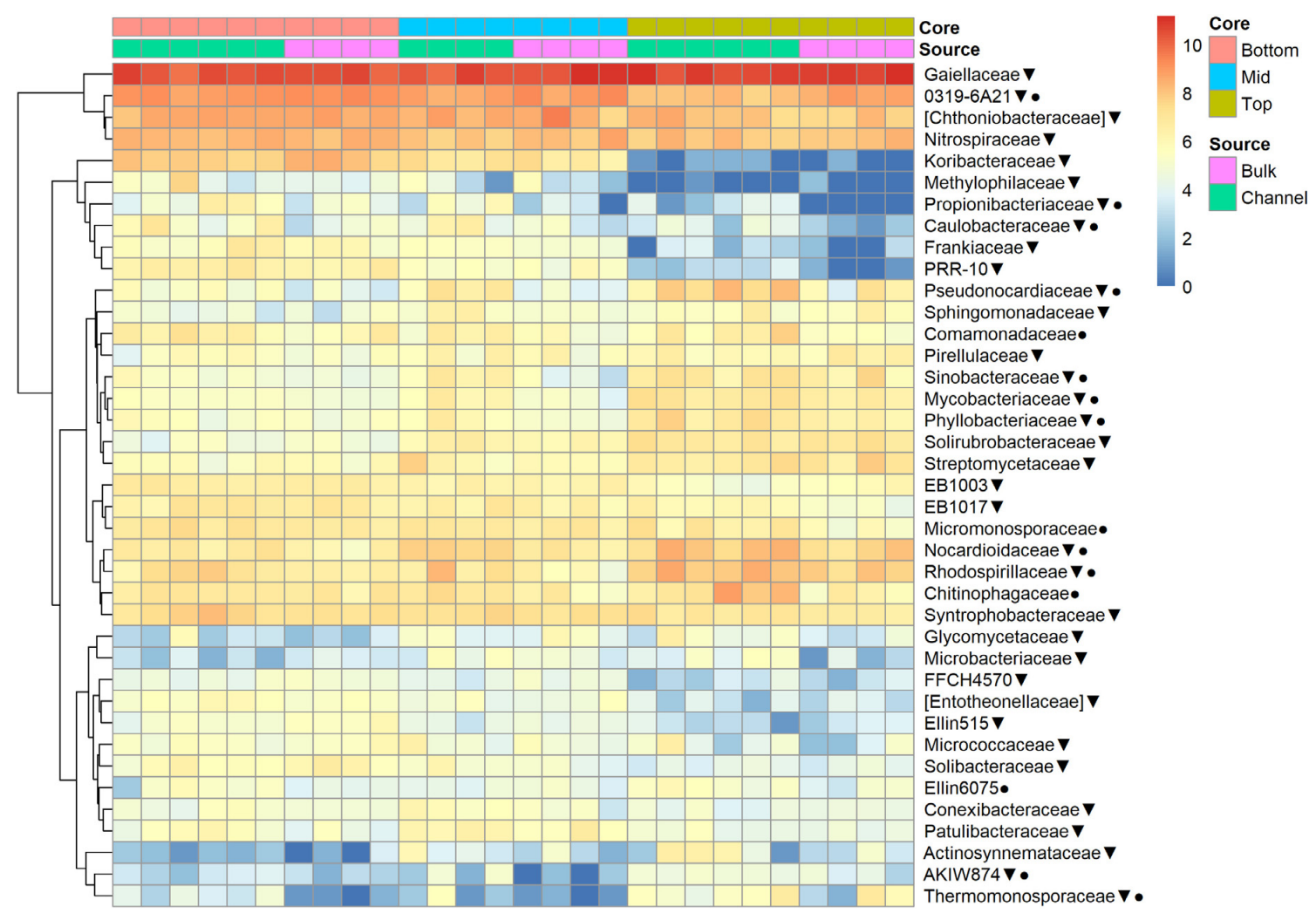

FIGURE 4 | Heatmap of bacterial family abundances [ $\log _{2}(1+x)$-transformed rarefied sequence counts] in different soil cores and drilosphere samples. Top, mid, and bottom refer to slope positions. Triangles indicate families that differ significantly among slope positions (Kruskal-Wallis test, FDR-adjusted $p$-value $<0.1)$. Circles indicate families that differ significantly between bulk versus earthworm channel soil (Kruskal-Wallis test, FDR-adjusted $p$-value $<0.1$ ).

of denitrifying genes tended to be greater in cores from bottom-slope positions compared to the top slope, although the differences were not always significant. Denitrifying genes were of very low abundance in samples taken from the top slope core, with nirK and nirS being below the detection limit in bulk soil ( 4 of 4 and 2 of 4 samples, respectively), and only one sample of drilosphere soil. Individually, the abundance of nirK, but not nirS, differed significantly between bulk and drilosphere soil (nested ANOVA $p=0.028$ and $p=0.17$, respectively); however, when comparing bulk and drilosphere samples within each core, a difference was observed between the bulk and channel soil for nirK at mid-slope ( $t$-test, $p=0.027)$ and nirS at the bottom-slope ( $t$-test, $p=0.066)$. Moreover, when considered together $($ nirK + nirS $)$, denitrifying gene abundances were significantly greater in the drilosphere versus bulk soil (nested ANOVA, $F=5.47, p=0.028$ ). When compared to the abundance of the 16S rRNA gene (ratio), both denitrification genes were enriched in DNA collected from the lower two slope positions compared to the top-slope (Figure 7 and Supplementary Table 4). The ratio of nirS/16S rRNA genes was greater in the bulk soil at the bottom- and mid-slope compared to the top-slope position; however, soil source was not a significant factor for either gene. The nos $Z$ gene was below the detectable limit (1000 copies $\mu l^{-1}$ DNA extract) in all soil samples.
The gene was amplified in soils from similar soil collections indicating the detection was limited by copy abundance rather than assay failure.

The relative abundances of many OTUs exhibited strong $(R>0.65)$ and significant $(p<0.001)$ correlations with absolute and relative abundances of nirK and nirS (Supplementary Figures 1, 2). These taxa represented diverse phyla, including Proteobacteria (19\% of OTUs), Acidobacteria (25\% of OTUs), Actinobacteria (28\% of OTUs), Verrucomicrobia ( $9 \%$ of OTUs), and Chloroflexi (9\% of OTUs), suggesting a broad diversity of bacteria were positively associated with denitrifiers. However, only one of these OTUs (OTU2688, classified to the order MND1 [beta-Proteobacteria]) varied significantly between bulk soil and earthworm channels (KW-test, $p=0.013$ ). In addition to individual OTUs, bacterial richness and diversity was positively correlated with abundances of nirK (Sobs: $R=0.53, p=0.006$; $\left.\mathrm{H}^{\prime}: R=0.68, p=0.0007 ; 1 / \mathrm{D}: R=0.72, p=0.0002\right)$ and nirs (Sobs: $R=0.56, p=0.008 ; \mathrm{H}^{\prime}: R=0.49, p=0.013 ; 1 / \mathrm{D}$ : $R=0.41, p=0.041)$.

\section{DISCUSSION}

Microbial communities in soil are shaped by innumerable interactions among chemical, physical, biological, and historical 


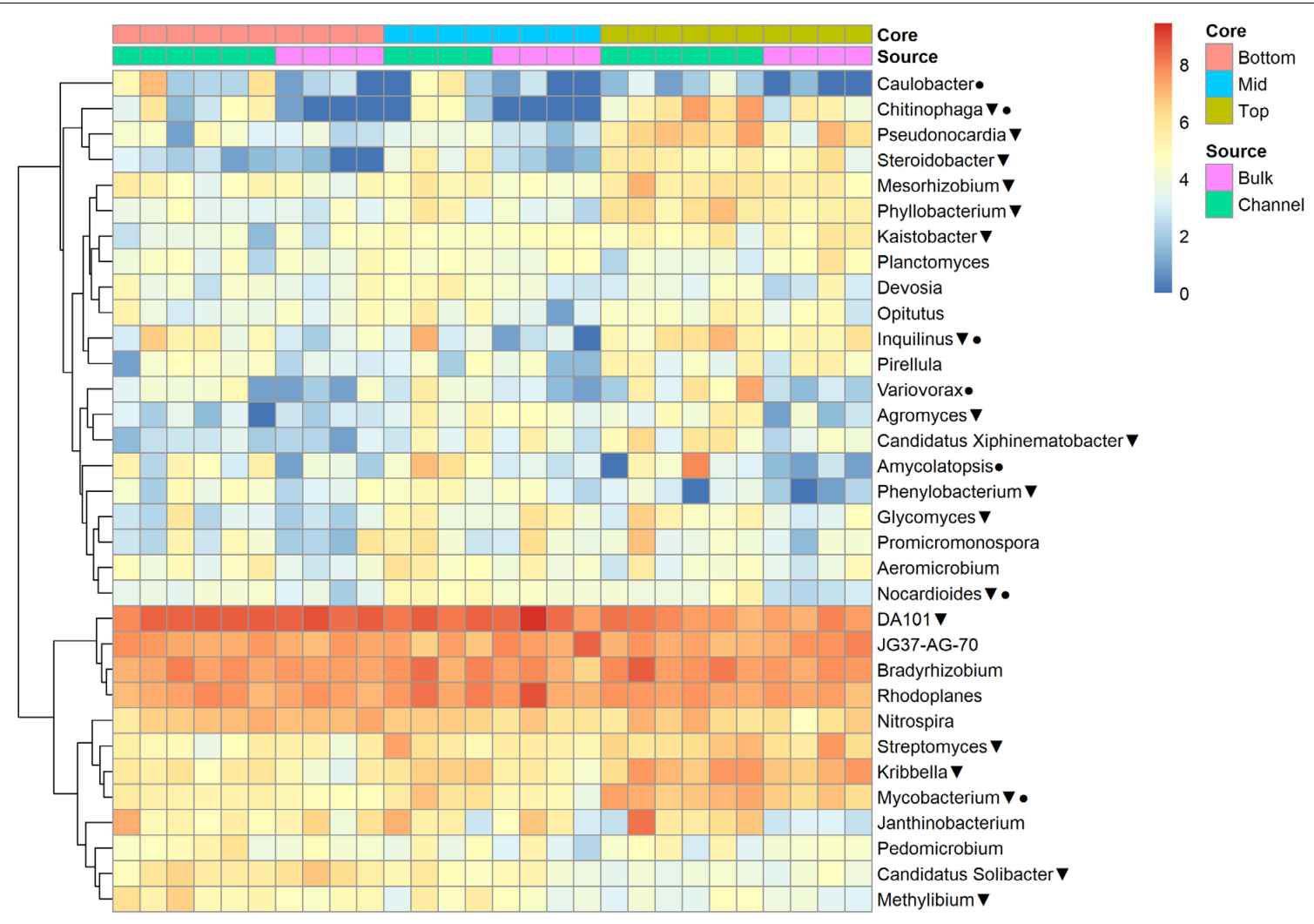

FIGURE 5 | Heatmap of bacterial genera abundances [ $\log _{2}(1+\mathrm{x})$-transformed rarefied sequence counts] in different soil cores and drilosphere samples. Triangles indicate genera that differ significantly among slope positions (Kruskal-Wallis test, FDR-adjusted $p$-value $<0.1$ ). Circles indicate genera that differ significantly between bulk versus earthworm channel soil (Kruskal-Wallis test, FDR-adjusted $p$-value $<0.1$ ).

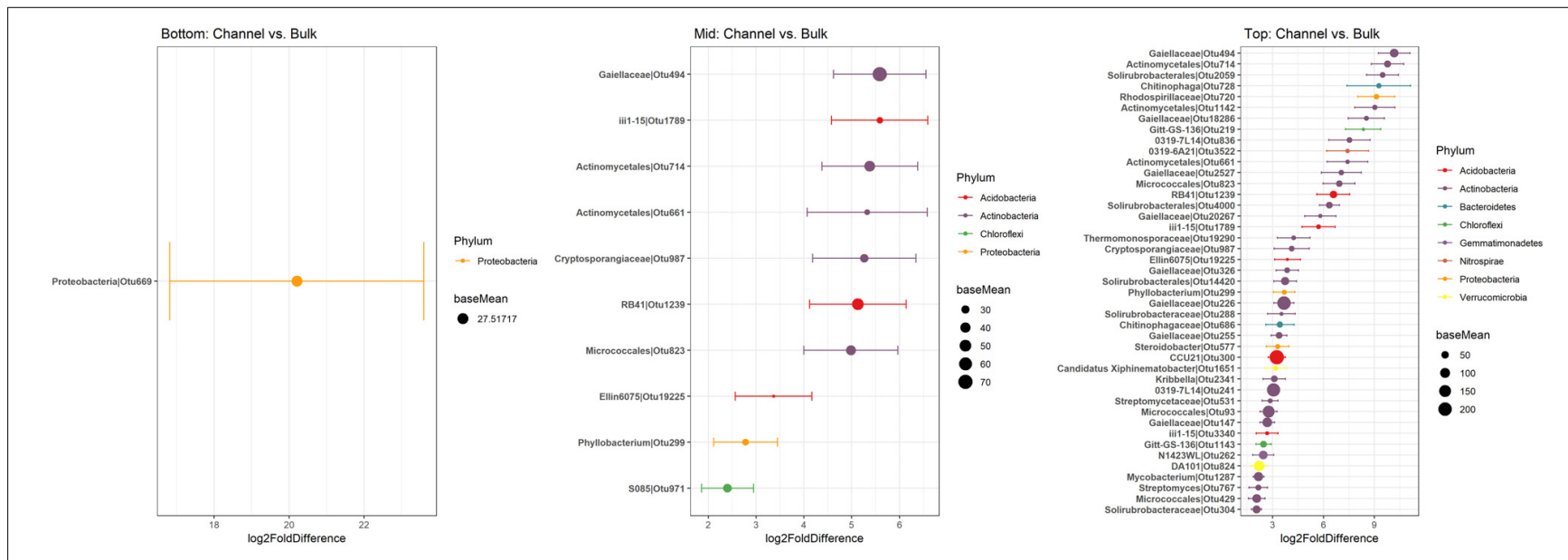

FIGURE 6 | Differentially abundant OTUs between bulk and earthworm channel soil. The $x$-axis represents the DESeq2 estimated log2-fold difference in abundances between bulk and earthworm channel soil. Points are colored by the phylum to which they were classified and the size of the points indicates the mean abundance of that OTU among all samples.

variables. This work provides insight into the roles of earthworm burrowing and landscape variability, two important features in no-till cropping systems in the Palouse region, in determining soil bacterial community composition, diversity, and abundance of denitrifying populations. Bacterial community composition was related primarily to the slope position (top-, mid-, or bottom-slope), suggesting that the slope position within fields is a major determinant of within-field community variation. Many genera within the Actinobacteria were more prevalent in soils from the top-slope, including Streptomyces, Pseudonocardia, 
TABLE 1 | Mean ( \pm standard deviation) of bacterial richness and diversity.

\begin{tabular}{|c|c|c|c|c|}
\hline \multirow[b]{2}{*}{ Landscape position } & \multirow[b]{2}{*}{ Soil source } & \multicolumn{3}{|c|}{ Bacterial richness and diversity } \\
\hline & & Richness & Shannon H' & Simpsons 1/D \\
\hline Bottom & Channel & $1310 \pm 174 a$ & $6.20 \pm 0.15 a$ & $232.92 \pm 41.35 a$ \\
\hline \multirow[t]{2}{*}{ Mid } & Bulk & $1213 \pm 193 a b$ & $5.85 \pm 0.21 b c$ & $138.85 \pm 32.21 b$ \\
\hline & Channel & $1366 \pm 137 a$ & $6.12 \pm 0.10 a b$ & $199.45 \pm 10.80 a$ \\
\hline \multirow{5}{*}{ Top } & Core & 22.8 & 35.9 & 30.41 \\
\hline & & $(<0.0001)$ & $(<0.0001)$ & $(<0.0001)$ \\
\hline & Source & 2.43 & 13.55 & 19.13 \\
\hline & & $(0.13)$ & $(0.001)$ & $(0.0002)$ \\
\hline & Core $\times$ source & 1.13 & 1.32 & 0.565 \\
\hline
\end{tabular}

Different letters within each column represent significant differences among groups. ANOVA F-values and p-values (parentheses) are presented for the effects of Core, Source, and the Core $\times$ source interaction. Values in bold indicate significance at $p<0.05$.

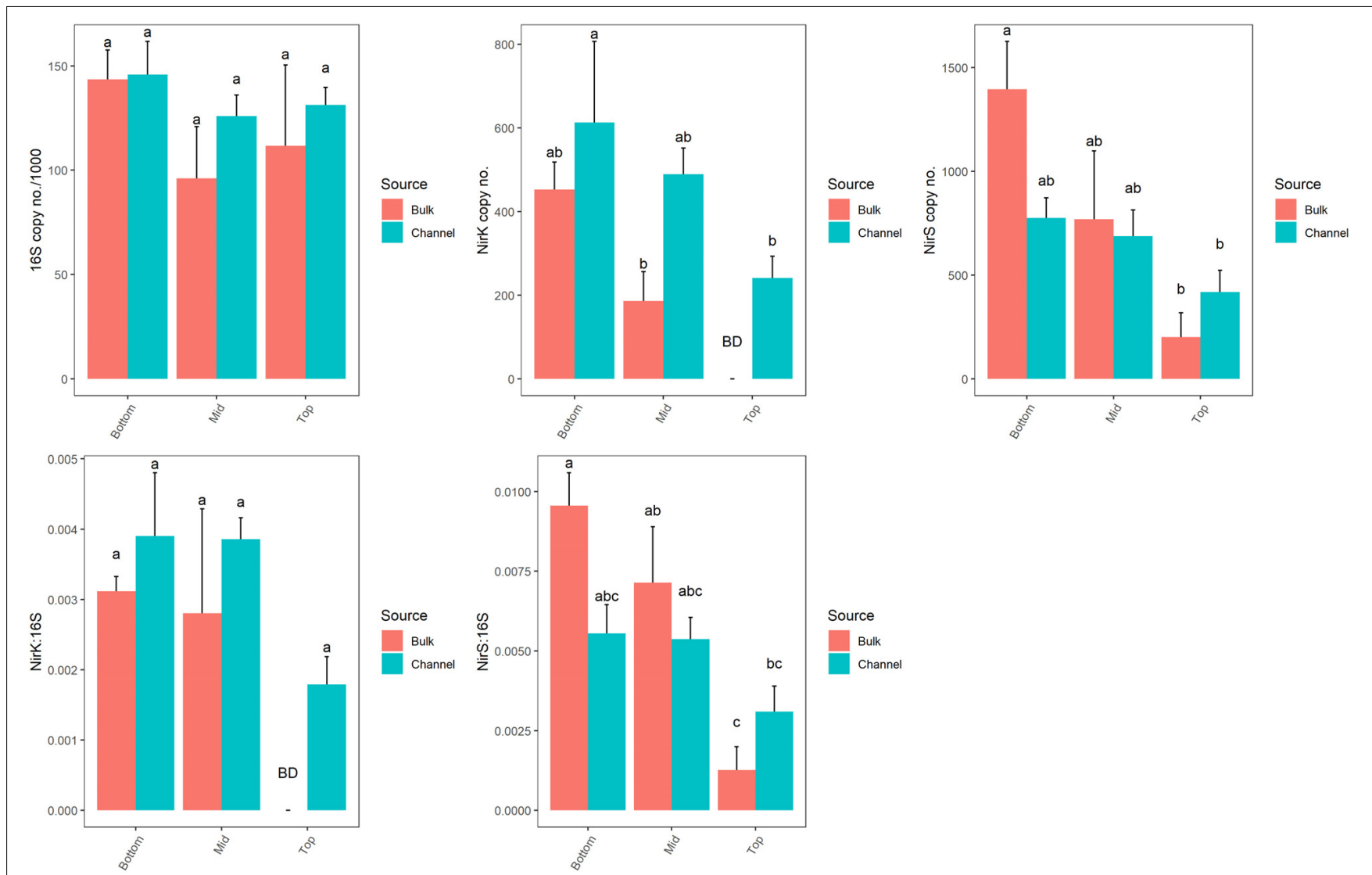

FIGURE 7 | Abundances of 16S rRNA, nirK and nirS gene copy numbers from bulk soil and earthworm channels among landscape slope positions. Different letters above bars indicate statistically significant differences (Tukey's HSD, $p<0.05$ ). A statistical evaluation of differences is also presented in Supplementary Table $\mathbf{5}$.

Kribbella, and Mycobacterium. In contrast, Candidatus Solibacter (Acidobacteria) and DA101 (Verrucomicrobia) were more prevalent in mid- and bottom-slope positions. Top-slopes in this system are highly eroded, have reduced water availability, and have lower crop yields and residue biomass compared to the bottom slopes, whereas the bottom-slopes are expected to have a deeper soil profile due to deposition of soil that eroded from higher slope positions (Fiez et al., 1995). Actinomycetes, especially Streptomyces and Pseudonocardia, are well-adapted to dry soil conditions and can survive for 
decades as desiccation-resistant spores (Barka et al., 2016). Moreover, these genera, as well as Chitinophaga, are important in disease suppression and degradation of complex organic compounds (Chung et al., 2012). A recently sequenced genome of Candidatus Solibacter suggests that this organism is a mixotroph that, in addition to being exceptionally adept at degrading cellulose and other plant compounds, can also use carbon monoxide as an energy source (Ward et al., 2009; Challacombe et al., 2011). Moreover, members of this genus encode genes for denitrification. Very little information exists on the biology of the genus DA101; however, the sole cultured representative of its family Chthoniobacteraceae (Chthoniobacter flavus) encodes nirK (Coyotzi et al., 2017) and is involved in the breakdown of organic substrates (Kant et al., 2011). Together, these results suggest that landscape variation in bacterial community composition, driven by within-field gradients in soil moisture, plant productivity, and soil chemistry due to landscape topology, contribute to differences in key microbial community functions such as carbon and nutrient cycling, denitrification, and plant disease suppression. However, due to sampling limitations we were unable to obtain detailed information on soil characteristics. Thus, the impact of slope position and soil edaphic factors on soil communities were not the primary focus of this work and should be explored in greater detail in future studies.

Although slope position appeared to be the primary driver of bacterial community composition in this study, a small number of bacterial groups were significantly enriched in the earthworm drilosphere. These taxa included the families AKIW874 (Acidomicrobia) and Comamonadaceae (beta-Proteobacteria), and members of the genera Variovorax (family Comamonadaceae) and Amycolatopsis. Variovorax and Amycolatopsis are both common soil bacteria. Variovorax is a possible endosymbiont of nephridia of some earthworm species and is frequently a part of earthworm gut microflora (Davidson et al., 2013). Variovorax is often involved in degradation of xenobiotic compounds, can act as a plant growth promoter (Pereira et al., 2016), and has previously been shown to be enriched in soil amended with earthworms (Cao et al., 2015). Amycolatopsis species are frequent producers of geosmin, a volatile natural product responsible for the "earthy" smell of soil, which is hypothesized to attract earthworms and springtails to act as dispersal vectors as bacterial spores adhere to exoskeletons or epidermis and are transported with the animal (Hopwood, 2007; Zhao et al., 2010). Dispersal and deposition of antibiotic-producing actinomycetes, such as Amycolatopsis, may also influence the breakdown of plant residues via inhibition of more efficient decomposer fungi (van der Meij et al., 2017). Finally, since both Variovorax and Amycolatopsis also associate with plant roots, enrichment of these taxa in the drilosphere may subsequently increase plant root colonization and benefit plant health and productivity via growth promotion, protection from disease or xenobiotics, and enhanced nutrient cycling.

Most of the individual bacterial taxa enriched in drilosphere versus bulk soil were members of Actinobacteria, including Micrococcales, Gaiellaceae, Solirubrobacterales, and Mycobacterium. However, these taxa could not be classified to finer taxonomic levels and may represent uncultured or understudied species. Very little is known about the members of Gaiella or Solirubrobacterales, which were recently proposed as separate families within the Class Thermoleophilia (Albuquerque et al., 2011). Members of the Micrococcales may be especially well-adapted to growth in low moisture environments, perhaps due to their ability to produce biofilms. Bacterial biofilm residues may contribute to the stability of earthworm channels in soil. Mycobacterium species, including potentially pathogenic M. tuberculosis, has been demonstrated to be efficiently dispersed in soil via earthworm activity (Fischer et al., 2003). Together, enrichment of many poorly characterized taxa in the drilosphere suggest that many bacterial groups have unidentified direct associations with earthworms or effectively colonize burrow channels differently from the bulk soil. However, because the difference between drilosphere and bulk soil communities was strongest in top-slope positions (accounting for 39\% of variation in community composition), intermediate in mid-slope positions (accounting for $22 \%$ of variation in community composition), and weakest in bottom-slope positions (accounting for 14\% of variation in community composition), the impact of earthworm burrows on specific OTUs also depended on slope position. The top-slope position had the most rapid saturated hydraulic conductivity, suggesting these soils were more porous, and may reflect a more extensive network of deeper worm channels. Thus, the influence of earthworm burrowing activity on microbial community structure in the drilosphere appears to depend on landscape and slope characteristics. This variation may be due to differences in earthworm activity across the landscape, different ages of earthworm channels, or differences in soil properties that structure microbial communities in bulk soil.

In addition to differences in bacterial community composition between drilosphere and bulk soil, earthworm burrows also harbored a greater diversity of bacteria. The consistently higher bacterial diversity within burrows is likely due to the greater availability of $\mathrm{C}$ and $\mathrm{N}$ in earthworm burrows than non-impacted (or bulk) soil (Tiunov and Scheu, 1999). Specifically, earthworms provide crucial resources for bacterial activity by pulling large amounts of organic residues below ground, leaving mucilage and casts within burrows, and thus may contribute to the maintenance of microbial diversity in burrow linings. Moreover, earthworm activity or increased water infiltration rates may generate higher rates of dispersal of microbial populations among soil strata within earthworm burrows and contribute to the observed differences in bacterial diversity.

Similar to bacterial community composition, the abundance of denitrification genes (nirK and nirS) varied primarily among slope positions, where they were more abundant in bottom-slope position and least abundant in top-slope position. This difference in the gene distribution at the $50 \mathrm{~cm}$ depth core is consistent with previous work by Shrewsbury et al. (2016) at the same site $(\mathrm{CAF})$, which revealed that in the $0-5 \mathrm{~cm}$ depth there were differences in the abundance of denitrifying genes between upper and lower slope positions, and that denitrifying gene abundances were related to total soil C. However, Shrewsbury et al. (2016) 
also found that variation in denitrifier gene abundances across the landscape were significant only in winter.

Despite potential seasonal variation in denitrifier gene abundances, nirK tended to be more abundant in earthworm burrows, suggesting that the drilosphere is a hotspot of bacterial denitrification in soil. Alternatively, because denitrifying bacteria are a key part of the earthworm gut microflora (Depkat-Jakob et al., 2010), the high abundance of nirK in burrows may reflect deposition of earthworm gut inhabitants. The bacterial genera Bradyrhizobium, Rhodoplanes, Streptomyces, and Janthinobacterium include denitrifiers (Shapleigh, 2013). Janthinobacterium was the only genera that was enriched in the burrow compared to bulk soil and only in the top core. The members of the families Solibacteraceae, Streptomycetaceae, Comamonadaceae, Koribacteraceae, and Propionibaceteriaceae were recently described as active denitrifiers in an agricultural soil (Coyotzi et al., 2017). Indeed, correlations among OTU abundances and abundances of denitrifying genes suggest that the denitrifiers in burrow linings in the deep drilosphere are primarily associated with the groups Actinobacteria, Acidobacteria, and Verrucomicrobia.

Taken together, the results of this study provide valuable insights into the roles that anecic earthworms play in structuring soil bacterial communities at different landscape positions. Bacterial communities were influenced by both slope position and earthworm activity. Increased bacterial diversity, as well as enrichment for denitrifiers and taxa related to nutrient cycling and plant health in the drilosphere suggests that increases in the densities and activities of anecic earthworms in no-till systems will impact nutrient dynamics and plant productivity via modification of the soil microbiome.

\section{REFERENCES}

Albuquerque, L., França, L., Rainey, F. A., Schumann, P., Nobre, M. F., and da Costa, M. S. (2011). Gaiella occulta gen. nov., sp. nov., a novel representative of a deep branching phylogenetic lineage within the class Actinobacteria and proposal of Gaiellaceae fam. Nov. And Gaiellales ord. nov. Syst. Appl. Microbiol. 34, 595-599. doi: 10.1016/j.syapm.2011.07.001

Andriuzzi, W. S., Bolger, T., and Schmidt, O. (2013). The drilosphere concept: fine-scale incorporation of surface residue-derived $\mathrm{N}$ and $\mathrm{C}$ around natural Lumbricus terrestris burrows. Soil Biol. Biochem. 64, 136-138. doi: 10.1016/j. soilbio.2013.04.016

Banfield, C. C., Dippold, M. A., Pausch, J., Hoang, D. T. T., and Kuzyakov, Y. (2017). Biopore history determines the microbial community composition in subsoil hotspots. Biol. Fertil. Soils 53, 573-588. doi: 10.1007/s00374-017-12011205

Barka, E. A., Vatsa, P., Sanchez, L., Gaveau-Vaillant, N., Jacquard, C., Klenk, H.-P., et al. (2016). Taxonomy, physiology, and natural products of Actinobacteria. Microbiol. Mol. Biol. Rev. 80, 1-43. doi: 10.1128/MMBR.000 19-15

Beloqui, A., Nechitaylo, T. Y., Lopez-Cortes, N., Ghazi, A., Guazzaroni, M.-E., Polaina, J., et al. (2010). Diversity of glycosyl hydrolases from cellulose-depleting communities enriched from casts of two earthworm species. Appl. Environ. Microbiol. 76, 5934-5946. doi: 10.1128/AEM.0090 $2-910$

Biswas, S., Lahiri, P., and Das, S. (2014). Isolation of predominant bacteriam from gut of earthworm Lampito mauritii for effective use in soil fertility. Curr. Sci. 107, 105-109.

\section{AUTHOR CONTRIBUTIONS}

DS, TP, and JJ-M designed the study. EB, KK, JN, and DH provided the soil cores for the study. DS conducted the sequencing and microbial community analysis. CR conducted the qPCR of bacterial genes. DS and TP wrote the initial draft of the manuscript. JJ-M, CR, EB, KK, JN, and DH contributed to revising the manuscript.

\section{FUNDING}

This study was funded by the Agricultural Research Service, United States Department of Agriculture (USDA) via a Postdoctoral Research Associate Award to DS and the REACCH (Regional Approaches to Climate Change-Pacific Northwest Agriculture) award \#2011-68002-30191 from the USDA National Institute of Food and Agriculture.

\section{ACKNOWLEDGMENTS}

The authors would like to thank the contributions of Caroline Melle (Agricultural Research Service, United States Department of Agriculture) in the technical aspects of this study.

\section{SUPPLEMENTARY MATERIAL}

The Supplementary Material for this article can be found online at: https://www.frontiersin.org/articles/10.3389/fmicb. 2019.01339/full\#supplementary-material

Brown, G. G., Barois, I., and Lavelle, P. (2000). Regulation of soil organic matter dynamics and microbial activityin the drilosphere and the role of interactionswith other edaphic functional domains. Europ. J. Soil Biol. 36, 177-198.

Burtelow, A. E., Bohlen, P. J., and Groffman, P. M. (1998). Influence of exotic earthworm invasion on soil organic matter, microbial biomass and denitrification potential in forest soils of the northeastern United States. Appl. Soil Ecol. 9, 197-202. doi: 10.1016/S0929-1393(98)00075-74

Byzov, B. A., Nechitaylo, T. Y., Bumazhkin, B. K., Kurakov, A. V., Golyshin, P. N., and Zvyagintsev, D. G. (2009). Culturable microorganisms from the earthworm digestive tract. Microbiology 78, 360-368. doi: 10.1134/S00262617090 30151

Cameron, E. K., Cahill, J. F., and Bayne, E. M. (2014). Root foraging influences plant growth responses to earthworm foraging. PLoS One 9:e108873. doi: 10. 1371/journal.pone.0108873

Cao, J., Huang, Y., and Wang, C. (2015). Rhizosphere interactions between earthworms (Eisenia fetida) and arbuscular mycorrhizal fungus (Funneliformis mosseae) promote utilization efficiency of phytate phosphorus in maize. Appl. Soil Ecol. 94, 30-39. doi: 10.1016/j.apsoil.2015.05.001

Caporaso, J. G., Kuczynski, J., Stombaugh, J., Bittinger, K., Bushman, F. D., Costello, E. K., et al. (2010). QIIME allows analysis of high-throughput community sequencing data. Nat. Methods 7, 335-336. doi: 10.1038/nmeth. f.303

Challacombe, J. F., Eichorst, S. A., Hauser, L., Land, M., Xie, G., and Kuske, C. R. (2011). Biological consequences of ancient gene acquisition and duplication in the large genome of Candidatus Solibacter usitatus Ellin6076. PLoS One 6:e24882. doi: 10.1371/journal.pone.0024882 
Chen, C., and Whalen, J. K. (2016). Earthworm interactions with denitrifying bacteria are scale-dependent: evidence from physiological to riparian ecosystem scales. Basic Appl. Ecol. 17, 1-10. doi: 10.1016/j.baae.2015.12.007

Chung, E. J., Park, T. S., Jeon, C. O., and Chung, Y. R. (2012). Chitinophaga oryziterrae sp. nov., isolated from the rhizosphere soil of rice (Oryza sativa L.). Int. J. Syst. Evol. Microbiol. 62, 3030-3035. doi: 10.1099/ijs.0.036442-36440

Cortez, J. (1998). Field decomposition of leaf litters: relationships between decomposition rates and soil moisture, soil temperature and earthworm activity. Soil Biol. Biochem. 30, 783-793. doi: 10.1016/S0038-0717(97)0016 3-166

Coyotzi, S., Doxey, A. C., Clark, I. D., Lapen, D. R., Van Cappellen, P., and Neufeld, J. D. (2017). Agricultural soil denitrifiers possess extensive nitrite reductase gene diversity: agricultural soil denitrifiers. Environ. Microbiol. 19, 1189-1208. doi: $10.1111 / 1462-2920.13643$

Curry, J. P., and Schmidt, O. (2007). The feeding ecology of earthworms - a review. Pedobiologia 50, 463-477. doi: 10.1016/j.pedobi.2006.09.001

Davidson, S. K., Powell, R., and James, S. (2013). A global survey of the bacteria within earthworm nephridia. Mol. Phylogenet. Evol. 67, 188-200. doi: 10.1016/ j.ympev.2012.12.005

Depkat-Jakob, P. S., Hilgarth, M., Horn, M. A., and Drake, H. L. (2010). Effect of earthworm feeding guilds on ingested dissimilatory nitrate reducers and denitrifiers in the alimentary canal of the earthworm. Appl. Environ. Microbiol. 76, 6205-6214. doi: 10.1128/AEM.01373-1310

Devliegher, W., and Verstraete, W. (1997). Microorganisms and soil physicochemical conditions in the drilosphere of Lumbricus terrestris. Soil Biol. Biochem. 29, 1721-1729. doi: 10.1016/S0038-0717(97)00068-60

Don, A., Steinberg, B., Schöning, I., Pritsch, K., Joschko, M., Gleixner, G., et al. (2008). Organic carbon sequestration in earthworm burrows. Soil Biol. Biochem. 40, 1803-1812.

Edgar, R. C. (2013). UPARSE: highly accurate OTU sequences from microbial amplicon reads. Nat. Methods 10, 996-998. doi: 10.1038/nmeth.2604

Edwards, C. A., and Lofty, J. R. (1980). Effects of earthworm inoculation upon the root growth of direct drilled cereals. J. Appl. Ecol. 17:533. doi: 10.2307/2402635

Edwards, U., Rogall, T., Blöcker, H., Emde, M., and Böttger, E. C. (1989). Isolation and direct complete nucleotide determination of entire genes. characterization of a gene coding for 16S ribosomal RNA. Nucleic Acids Res. 17, 7843-7853. doi: 10.1093/nar/17.19.7843

Fiez, T. E., Pan, W. L., and Miller, B. C. (1995). Nitrogen use efficiency of winter wheat among landscape positions. Soil Sci. Soc. Am. J. 59, 1666-1671. doi: 10.2136/sssaj1995.03615995005900060023x

Fischer, O. A., Matlova, L., Bartl, J., Dvorska, L., Svastova, P., du Maine, R., et al. (2003). Earthworms (Oligochaeta, Lumbricidae) and mycobacteria. Vet. Microbiol. 91, 325-338.

Gohl, D., MacLean, A., Hauge, A., Becker, A., Walek, D., and Beckman, K. (2016). An optimized protocol for high-throughput amplicon-based microbiome profiling. Protoc. Exch. 10, doi: 10.1007/978-1-4939-7136-7_23

Görres, J. H., Savin, M. C., and Amador, J. A. (2001). Soil micropore structure and carbon mineralization in burrows and casts of an anecic earthworm (Lumbricus terrestris). Soil Biol. Biochem. 33, 1881-1887. doi: 10.1016/S00380717(01)00068-62

Hoang, D. T. T., Pausch, J., Razavi, B. S., Kuzyakova, I., Banfield, C. C., and Kuzyakov, Y. (2016a). Hotspots of microbial activity induced by earthworm burrows, old root channels, and their combination in subsoil. Biol. Fertil. Soils 52, 1105-1119. doi: 10.1007/s00374-016-1148-y

Hoang, D. T. T., Razavi, B. S., Kuzyakov, Y., and Blagodatskaya, E. (2016b). Earthworm burrows: kinetics and spatial distribution of enzymes of C-. N- and P- cycles. Soil Biol. Biochem. 99, 94-103. doi: 10.1016/j.soilbio.2016.04.021

Hopwood, D. A. (2007). Streptomyces Nature and Medicine: The Antibiotic Makers?. New York, NY: Oxford University Press.

Horn, M. A., Drake, H. L., and Schramm, A. (2006). Nitrous oxide reductase genes (nosZ) of denitrifying microbial populations in soil and the earthworm gut are phylogenetically similar. Appl. Environ. Microbiol. 72, 1019-1026. doi: 10.1128/AEM.72.2.1019-1026.2006

Horn, M. A., Schramm, A., and Drake, H. L. (2003). The Earthworm gut: an ideal habitat for ingested N2O-producing microorganisms. Appl. Environ. Microbiol. 69, 1662-1669. doi: 10.1128/AEM.69.3.1662-1669.2003

Huggins, D. R., Kruger, C. E., Painter, K. M., and Uberuaga, D. P. (2014). Site-specific trade-offs of harvesting cereal residues as biofuel feedstocks in dryland annual cropping systems of the Pacific Northwest. USA. BioEnergy Res. 7, 598-608. doi: 10.1007/s12155-014-943 8-9434

Ihssen, J., Horn, M. A., Matthies, C., Gössner, A., Schramm, A., and Drake, H. L. (2003). N2O-producing microorganisms in the gut of the earthworm Aporrectodea caliginosa are indicative of ingested soil bacteria. Appl. Environ. Microbiol. 69, 1655-1661.

Kant, R., van Passel, M. W. J., Palva, A., Lucas, S., Lapidus, A., Glavina del Rio, T., et al. (2011). Genome sequence of Chthoniobacter flavus Ellin428, an aerobic heterotrophic soil bacterium. J. Bacteriol. 193, 2902-2903. doi: 10.1128/JB. 00295-211

Karsten, G., and Drake, H. (1997). Denitrifying bacteria in the earthworm gastrointestinal tract and in vivo emission of nitrous oxide (N2O) by earthworms. Appl. Environ. Microbiol. 63, 1878-1882.

Lavelle, P., Spain, A., Blouin, M., Brown, G., Decaens, T., Grimaldi, M., et al. (2016). Ecosystem engineers in a self-organized soil: a review of concepts and future research questions. Soil Sci. 181, 91-109.

Love, M. I., Huber, W., and Anders, S. (2014). Moderated estimation of fold change and dispersion for RNA-seq data with DESeq2. Genome Biol. 15:550. doi: 10.1186/s13059-014-0550-558

Matthies, C., Griebhammer, A., Schmittroth, M., and Drake, H. (1999). Evidence for involvement of gut-associated denitrifying bacteria in emission of nitrous oxide (N2O) by earthworms obtained for garden and forest soils. Appl. Environ. Microbiol. 65, 3599-3604.

Nebert, L. D., Bloem, J., Lubbers, I. M., and van Groenigen, J. W. (2011). Association of earthworm-denitrifier interactions with increased emission of nitrous oxide from soil mesocosms amended with crop residue. Appl. Environ. Microbiol. 77, 4097-4104. doi: 10.1128/AEM.000 33-11

Nechitaylo, T. Y., Yakimov, M. M., Godinho, M., Timmis, K. N., Belogolova, E., Byzov, B. A., et al. (2010). Effect of the earthworms Lumbricus terrestris and Aporrectodea caliginosa on bacterial diversity in soil. Microb. Ecol. 59, 574-587. doi: 10.1007/s00248-009-9604-y

Oksanen, J., Blanchette, F. G., Friendly, M., Kindt, R., Legendre, P., McGlinn, D., et al. (2016). Vegan: Community ecology package. Available at: https://github. com/vegandevs/vegan (accessed October 24, 2017).

Øvreås, L., Forney, L., Daae, F., and Torsvik, V. (1997). Distribution of bacterioplankton in meromictic lake saelenvannet, as determined by denaturing gradient gel electrophoresis of PCR-amplified gene fragments coding for $16 \mathrm{~S}$ rRNA. Appl. Environ. Microbiol. 63, 3367-3373.

Peigné, J., Cannavaciuolo, M., Gautronneau, Y., Aveline, A., Giteau, J. L., and Cluzeau, D. (2009). Earthworm populations under different tillage systems in organic farming. Soil Tillage Res. 104, 207-214. doi: 10.1016/j.still.2009.02.011

Pereira, S. I. A., Monteiro, C., Vega, A. L., and Castro, P. M. L. (2016). Endophytic culturable bacteria colonizing Lavandula dentata L. plants: isolation, characterization and evaluation of their plant growth-promoting activities. Ecol. Eng. 87, 91-97. doi: 10.1016/j.ecoleng.2015.11.033

Potvin, L. R., and Lilleskov, E. A. (2017). Introduced earthworm species exhibited unique patterns of seasonal activity and vertical distribution, and Lumbricus terrestris burrows remained usable for at least 7 years in hardwood and pine stands. Biol. Fertil. Soils 53, 187-198. doi: 10.1007/s00374-016-1173-x

Pulleman, M., Six, J., Uyl, A., Marinissen, J. C. Y., and Jongmans, A. G. (2005). Earthworms and management affect organic matter incorporation and microaggregate formation in agricultural soils. Appl. Soil Ecol. 29, 1-15. doi: 10.1016/j.apsoil.2004.10.003

R Core Team (2016). R: A Language and Environment for Statistical Computing. Vienna: R Foundation for Statistical Computing.

Reardon, C. L., Gollany, H. T., and Wuest, S. B. (2014). Diazotroph community structure and abundance in wheat-fallow and wheat-pea crop rotations. Soil Biol. Biochem. 69, 406-412. doi: 10.1016/j.soilbio.2013.10.038

Rothwell, A., Chaney, K., and Haydock, P. (2011). "The impact of cultivation techniques on earthworm populations," in Biology of Earthworms, ed. A. Karaca (Berlin: Springer), 159-172.

Shapleigh, J. P. (2013). “Denitrifying prokaryotes," in The Prokaryotes, eds E. Rosenberg, E. F. DeLong, S. Lory, E. Stackebrandt, and F. Thompson (Berlin: Springer), 405-425.

Shrewsbury, L. H., Smith, J. L., Huggins, D. R., Carpenter-Boggs, L., and Reardon, C. L. (2016). Denitrifier abundance has a greater influence on denitrification 
rates at larger landscape scales but is a lesser driver than environmental variables. Soil Biol. Biochem. 103, 221-231.

Stromberger, M. E., Keith, A. M., and Schmidt, O. (2012). Distinct microbial and faunal communities and translocated carbon in Lumbricus terrestris drilospheres. Soil Biol. Biochem. 46, 155-162. doi: 10.1016/j.soilbio.2011.11.024

Svensson, B. H., Boström, U., and Klemedtson, L. (1986). Potential for higher rates of denitrification in earthworm casts than in the surrounding soil. Biol. Fertil. Soils 2, 147-149. doi: 10.1007/BF00257593

Thakuria, D., Schmidt, O., Finan, D., Egan, D., and Doohan, F. M. (2010). Gut wall bacteria of earthworms: a natural selection process. ISME J. 4, 357-366. doi: 10.1038/ismej.2009.124

Tiunov, A. V., Bonkowski, M., Bonkowski, M., Tiunov, J. A., and Scheu, S. (2001). Microflora, protozoa and nematoda in Lumbricus terrestris burrow walls: a laboratory experiment. Pedobiologia 45, 46-60. doi: 10.1078/0031-40564067

Tiunov, A. V., and Kuznetsova, N. A. (2000). Environmental activity of earthworms (Lumbricus terrestris L.) and the spatial organization of soil communities]. Izv. Akad. Nauk. Ser. Biol. 5, 607-616.

Tiunov, A. V., and Scheu, S. (1999). Microbial respiration, biomass, biovolume and nutrient status in burrow walls of Lumbricus terrestris L. (Lumbricidae). Soil Biol. Biochem. 31, 2039-2048. doi: 10.1016/S0038-0717(99)0012 $7-123$

USDA (1978). Palouse Cooperative River Basin Study: Soil Conservation Service, Forest Service, and Economics and Cooperative Service. Washington, DC: U.S. Goverment Printing Office.

van der Meij, A., Worsley, S. F., Hutchings, M. I., and van Wezel, G. P. (2017). Chemical ecology of antibiotic production by actinomycetes. FEMS Microbiol. Rev. 41, 392-416. doi: 10.1093/femsre/fux005

van Groenigen, J. W., Lubbers, I. M., Vos, H. M., Brown, G. G., De Deyn, G. B., and van Groenigen, K. J. (2014). Earthworms increase plant production: a meta-analysis. Sci. Rep. 4:6365. doi: 10.1038/srep06365
Walsh, C. L., and Johnson-Maynard, J. L. (2016). Earthworm distribution and density across a climatic gradient within the Inland Pacific Northwest cereal production region. Appl. Soil. Ecol. 104, 104-110.

Wang, Q., Garrity, G. M., Tiedje, J. M., and Cole, J. R. (2007). Naive Bayesian classifier for rapid assignment of rRNA sequences into the new bacterial taxonomy. Appl. Environ. Microbiol. 73, 5261-5267. doi: 10.1128/AEM.000 62-67

Ward, N. L., Challacombe, J. F., Janssen, P. H., Henrissat, B., Coutinho, P. M., Wu, M., et al. (2009). Three genomes from the phylum acidobacteria provide insight into the lifestyles of these microorganisms in soils. Appl. Environ. Microbiol. 75, 2046-2056. doi: 10.1128/AEM.02294-2298

Willoughby, G. L., Kladivko, E. J., and Reza Savabi, M. (1997). Seasonal variations in infiltration rate under no-till and conventional (disk) tillage systems as affected by Lumbricus terrestris activity. Soil Biol. Biochem. 29, 481-484. doi: 10.1016/S0038-0717(96)00039-39

Zhao, W., Zhong, Y., Yuan, H., Wang, J., Zheng, H., Wang, Y., et al. (2010). Complete genome sequence of the rifamycin SV-producing Amycolatopsis mediterranei U32 revealed its genetic characteristics in phylogeny and metabolism. Cell Res. 20, 1096-1108. doi: 10.1038/cr.2010.87

Conflict of Interest Statement: The authors declare that the research was conducted in the absence of any commercial or financial relationships that could be construed as a potential conflict of interest.

Copyright (c) 2019 Schlatter, Reardon, Johnson-Maynard, Brooks, Kahl, Norby, Huggins and Paulitz. This is an open-access article distributed under the terms of the Creative Commons Attribution License (CC BY). The use, distribution or reproduction in other forums is permitted, provided the original author $(s)$ and the copyright owner(s) are credited and that the original publication in this journal is cited, in accordance with accepted academic practice. No use, distribution or reproduction is permitted which does not comply with these terms. 